\title{
METHODS FOR DESIGNING EXPERIMENTS TO STUDY THE ACTUAL CAUSES OF THE HOUSING CRISIS
}

\author{
ALANAZI TALAL ABDULRAHMAN* \\ Department of Mathamtics, College of Science, University of Ha'il, Saudi Arabia \\ *Corresponding author: t.shyman@uoh.edu.sa
}

\begin{abstract}
In this paper, I use the edge design analysis, contrast method analysis and regression analysis to study the actual reasons that led to the housing crisis. Also, applications of the housing crisis in KSA have been obtained, for example, the extent of this phenomenon with two levels $(+,-)$.
\end{abstract}

\section{INTRODUCTION}

Having an appropriate house is perhaps the main issues for all individuals. The Universal Declaration of Human Rights stressed the privilege of each human to have an appropriate house. Subsequently, numerous investigations have since featured the significance of having reasonable homes that serve the necessities, everything being equal. This would help guarantee social and financial soundness for everybody and empower people to be more dynamic local area individuals. Because of a few significant socioeconomics, social, social and financial changes, numerous nations have confronted lodging issues and issues around the arrangement of appropriate houses over the most recent couple of many years. As of late, oil incomes have empowered the Gulf Cooperation Council nations to observe quick improvement that has changed them from helpless nations into cutting edge ones. Numerous advancements have additionally been seen. Because of such turn of events, the legislatures in Gulf Cooperation Council nations have progressed the urban areas and increased the living expectations through making upgrades to the monetary, social and metropolitan climate. Saudi

Received April 11 ${ }^{\text {th }}, 2021$; accepted May $4^{\text {th }}, 2021$; published May 25 ${ }^{\text {th }}, 2021$.

2010 Mathematics Subject Classification. 91B25.

Key words and phrases. the housing crisis; edge designs; contrast method; linear model; screening design; data analysis.

(C)2021 Authors retain the copyrights of their papers, and all open access articles are distributed under the terms of the Creative Commons Attribution License. 
Arabia, as the biggest nation of the Gulf Cooperation Council nations with complete land space of the Kingdom is around 1,960,582 sq. km. Likewise, as perhaps the most populated ones arriving at the quantity of 34710 million, as per Ministry of Municipal, Rural Affairs(See figure 1). This fast increment has caused lodging issues and lodging shortages( [1]).

\begin{tabular}{|c|c|c|c|c|c|}
\hline & 2015 & 2020 & 2025 & 2030 & 2035 \\
\hline Total population & 31,557 & 34,710 & 37,290 & 39,480 & 41,317 \\
\hline Urban population & 26,249 & 29,256 & 31,843 & 34,143 & 36,170 \\
\hline Level of urbanization (\%) & 83.2 & 84.3 & 85.4 & 86.5 & 87.5 \\
\hline \multicolumn{6}{|l|}{ Five largest urban Agglomerations } \\
\hline Riyadh & 6,218 & 7,231 & 7,953 & 8,547 & 9,058 \\
\hline Jeddah & 4,035 & 4,610 & 5,022 & 5,388 & 5,710 \\
\hline Makkah & 1,796 & 2,042 & 2,219 & 2,379 & 2,521 \\
\hline Al-Madinah & 1,299 & 1,489 & 1,625 & 1,744 & 1,848 \\
\hline Dammam & 1,080 & 1,253 & 1,376 & 1,478 & 1,566 \\
\hline Total population of the five largest agglomerations & 14,428 & 16,625 & 18,195 & 19,536 & 20,703 \\
\hline Five largest agglomerations as \% of urban population & 54.97 & 56.82 & 57.14 & 57.22 & 57.24 \\
\hline Five largest agglomerations as \% of total population & 45.72 & 47.90 & 48.79 & 49.48 & 50.12 \\
\hline
\end{tabular}

FiguRE 1. KSA Urbanization from 2015-2035

Notwithstanding, the nation has accomplished observable advancement in numerous areas and fields inside a brief timeframe. This is credited primarily to the expanded incomes delivered by oil trades. The lodging area is one of the areas that has seen huge improvement throughout the most recent couple of many years, both the lodging approaches of Saudi Arabia are portrayed by the giving of enormous help to this area to make the securing of houses simpler for the residents. All things considered, because of fast metropolitan turn of events, close by monetary and social changes, including movement to urban communities, diverse Region of Saudi Arabia have encountered major and continuous changes to the metropolitan climate and the occupants' ways of life.

These progressions have accordingly influenced the requirements, wants and goals of the occupants and additionally, the interest for lodging. Presently, the lodging areas in Saudi Arabia are confronting various difficulties, including, in addition to other things: a prerequisite to give an immense number of houses. There has been a reduction in the quantity of houses offered on reasonable installment plans. Expanded houses and property costs. Proprietorship rates waiting be raised as they have diminished throughout the most recent decade. More interest being created in the primary locale and urban areas. As inhabitants are the principle partners and major parts as far as the lodging issue, the investigation of their perspectives, lodging necessities and the variables influencing their current and future lodging choices would be useful in outlining 
future insights and plans. In light of the study's aftereffects of General Authority for Statistics,2018, the absolute number of homes busy with Saudi families made up (3591098) in 2018, contrasted with (3504690) in 2017. The quantity of people living in such abodes recorded (21420372), with a normal size of Saudi families coming to $(5,96)$, contrasted with $(5,97)$ in 2017 ( [2]). Nonetheless, the normal size can be gotten by partitioning the quantity of people by the complete number of families. It merits referencing here that the lodging issue in Saudi Arabia has pulled in the consideration of specialists from various fields and foundations ( [3]). Nonetheless, during this examination, it was noticed that there has been a lessening throughout the most recent couple of years in the quantity of scholastic investigations being attempted that attention on the examination of this issue according to the perspective of the inhabitants and their longings. Along these lines, this is the primary inspiration for the determination of the subject of this exploration.

A goal of this examination is to find the actual causes of the housing crisis in Saudi society. To accomplish this objective, this examination used subjective and quantitative information to decide the genuine purposes behind of the housing crisiss. This paper starts by the method using in different examples.

\section{METHOD}

\section{Target population and study sample}

The main technique used in this survey is that it is based on only statistics and statistical analysis that included 16 questions about housing crisis. The number of people who participated to answer these questions has reached 410 individual.

\section{Data collection}

By then learn the achievement levels for the concentrated on understudy using the sensible model. This is displayed in Table 1, which clarifies the information gathered. I have collected data using the techniques of application of edge design and supersaturated designs to study the housing crisis. Also, to analyse the data from both techniques and applying this data in the app of SPSS. 
TABLE 1. The reasons of the housing crisis in data

\begin{tabular}{|l|l|l|}
\hline Reasonsr & signal & Yes/No \\
\hline The banking sector & + & Yes \\
& - & No \\
\hline $\begin{array}{l}\text { The lack of the citizen's culture of the impor- } \\
\text { tance of house owning }\end{array}$ & + & Yes \\
\hline $\begin{array}{l}\text { The religion contributed in the housing crisis } \\
\text { by prohibiting the works of the banks }\end{array}$ & + & No \\
\hline Earth association and family extended roots & + & Yes \\
\hline The increasing prices of the real estate com- \\
pared wit individual's income
\end{tabular}


TABle 1. (cont.)

\begin{tabular}{|c|c|c|}
\hline $\begin{array}{l}\text { The limited availability of the residential lands } \\
\text { and their usability }\end{array}$ & $\begin{array}{l}+ \\
-\end{array}$ & $\begin{array}{l}\text { Yes } \\
\text { No }\end{array}$ \\
\hline The lack of the governmental service facilities & $\begin{array}{l}+ \\
-\end{array}$ & $\begin{array}{l}\text { Yes } \\
\text { No }\end{array}$ \\
\hline The rural exodus that has conquered the cities & $\begin{array}{l}+ \\
-\end{array}$ & $\begin{array}{l}\text { Yes } \\
\text { No }\end{array}$ \\
\hline The lack of the housing units offered & + & $\begin{array}{l}\text { Yes } \\
\text { No }\end{array}$ \\
\hline $\begin{array}{l}\text { The absence of the supervision over offices and } \\
\text { real estate companies }\end{array}$ & $\begin{array}{l}+ \\
-\end{array}$ & $\begin{array}{l}\text { Yes } \\
\text { No }\end{array}$ \\
\hline $\begin{array}{l}\text { The increasing of building materials and man- } \\
\text { power prices }\end{array}$ & $\begin{array}{l}+ \\
-\end{array}$ & $\begin{array}{l}\text { Yes } \\
\text { No }\end{array}$ \\
\hline $\begin{array}{l}\text { Real estate developer's' exploitation of resi- } \\
\text { dential lands }\end{array}$ & $\begin{array}{l}+ \\
-\end{array}$ & $\begin{array}{l}\text { Yes } \\
\text { No }\end{array}$ \\
\hline Y(Response) & Number & The individual's income \\
\hline
\end{tabular}




\section{How to select a sample}

A pre-plan comprising of six components and twelve preliminaries is chosen by edge design method. Then, a pre-plan comprising of 16 components and 14 preliminaries is chosen by supersaturated design method - These plans are considered taking all things together the information that has been placed in the past advances and if there should arise an occurrence of acquiring the entire plan is put the estimation of the reaction and the quantity of the individual who addressed the survey.

\section{Consolidating and adjusting distinctive examination technique}

The plan picked in the past advance is dissected utilizing the edges, supersaturated design and regression analysis methods. On the off chance that the elements that we get from the edge plan technique are equivalent to supersaturated designs, these elements are the genuine reasons for housing crisis.

\section{Application of DATA ANALYsis}

3.1. Use of the edge plans in screening tests. Statistical significance was analyzed using edge design analysis using the SPSS computer software to determine the actual causes that led to of the housing crisis in Saudi society. [4] have presented the edge plans. The edge relies upon a model-autonomous test that can be utilized for dynamic factors. To know the dynamic factors, the estimations are organizes into a gathering of E sets. In this methodology the estimations contrasts in just a single part. It is normal in screening tests, and suggests that practically all distinctions

$$
z_{i, j}:=y_{i}-y_{j}, \quad(i, j) \in E,
$$

More details about this method can be found in [5]. In order to address these ethical concerns, the following example are taken.

Example 3.1. Let $n=6$ and the lack of the governmental service facilitie $x_{1}$, the rural exodus that has conquered the cities $x_{2}$, the lack of the housing units offered $x_{3}$, the absence of the supervision over offices and real estate companies $x_{4}$, the increasing of building materials and manpower prices $x_{5}$ and real estate developer's' exploitation of residential lands $x_{6}$. 
TABLE 2. One replicate for Example 3.1.

\begin{tabular}{|c|c|c|c|c|c|c|c|}
\hline Run & $x_{1}$ & $x_{2}$ & $x_{3}$ & $x_{4}$ & $x_{5}$ & $x_{6}$ & $\mathrm{Y}$ \\
\hline 1 & + & + & - & + & + & + & 840 \\
2 & - & + & + & + & + & + & 10000 \\
3 & + & - & + & + & + & + & 2000 \\
4 & - & - & - & + & - & + & 900 \\
5 & - & - & - & + & + & - & 2000 \\
6 & - & - & - & - & + & + & 10000 \\
7 & - & + & - & + & + & + & 9000 \\
8 & - & - & + & + & + & + & 15000 \\
9 & + & - & - & + & + & + & 5000 \\
10 & - & - & - & - & - & + & 0 \\
11 & - & - & - & + & - & - & 3000 \\
12 & - & - & - & - & + & - & 3000 \\
\hline
\end{tabular}

Presently an investigation information in Table 2 (utilizing liner regreesion) with the program bundle SPSS. According to the findings of the final model it tends to be seen that the p-value from the Analysis of Variances table (Figure 2) is under 0.05, which is there is dynamic factor the poor system of the current housing plans $x_{3}$ and allow an evaluated liner show $Y=14900-6550 x_{3}+\epsilon$, with $R-s g=87.9 \% \epsilon$ of mean 8450 and standard deviation $\sigma=6325.77$. Also from the result, the residual is normal because p-value (0.130) is more than 0.05(See Figure 3). 


\begin{tabular}{|c|c|c|c|c|c|c|c|}
\hline \multicolumn{6}{|c|}{ Model Summary ${ }^{b}$} & & \\
\hline Model & $\mathrm{R}$ & R Square & & & $\begin{array}{l}\text { Std. Error of } \\
\text { the Estimate }\end{array}$ & & \\
\hline 1 & $.879^{\mathrm{a}}$ & .773 & & .501 & 4468.55681 & & \\
\hline \multicolumn{8}{|c|}{ a. Predictors: (Constant), x6, x5, x4, x3, x2, x1 } \\
\hline \multicolumn{8}{|c|}{ b. Dependent Variable: $y$} \\
\hline \multicolumn{8}{|c|}{ ANOVA $^{a}$} \\
\hline \multicolumn{2}{|l|}{ Model } & \multicolumn{2}{|c|}{$\begin{array}{l}\text { Sum of } \\
\text { Squares }\end{array}$} & df & Mean Square & $\mathrm{F}$ & Sig. \\
\hline \multirow[t]{3}{*}{1} & Regression & \multirow{2}{*}{\multicolumn{2}{|c|}{$\begin{array}{l}340330000.0 \\
99840000.00\end{array}$}} & 6 & 56721666.67 & \multirow[t]{3}{*}{2.841} & \multirow{3}{*}{$.136^{\mathrm{b}}$} \\
\hline & Residual & & & 5 & 19968000.00 & & \\
\hline & Total & 440170 & 100.0 & 11 & & & \\
\hline
\end{tabular}

a. Dependent Variable: $y$

b. Predictors: (Constant) $\times 6, \times 5, \times 4, \times 3, \times 2, \times 1$

\begin{tabular}{|c|c|c|c|c|c|c|}
\hline \multicolumn{7}{|c|}{ Coefficients $^{a}$} \\
\hline & & \multicolumn{2}{|c|}{ Unstandardized Coefficients } & \multirow{2}{*}{$\begin{array}{c}\text { Standardized } \\
\text { Coefficients } \\
\text { Beta } \\
\end{array}$} & \multirow[b]{2}{*}{ t } & \multirow[b]{2}{*}{ Sig. } \\
\hline \multicolumn{2}{|c|}{ Model } & B & Std. Error & & & \\
\hline 1 & (Constant) & 14900.000 & 4079.216 & & 3.653 & .015 \\
\hline & $\mathrm{x} 1$ & -700.000 & 1869.331 & -.100 & -.374 & .723 \\
\hline & $\mathrm{x} 2$ & 2550.000 & 1869.331 & .365 & 1.364 & 231 \\
\hline & x3 & 6550.000 & 1869.331 & .937 & 3.504 & .017 \\
\hline & $\mathrm{x} 4$ & -2750.000 & 1869.331 & -.393 & -1.471 & 201 \\
\hline & $\times 5$ & -1400.000 & 1869.331 & -.200 & -.749 & .488 \\
\hline & $\mathrm{x} 6$ & -350.000 & 1869.331 & -.050 & -.187 & .859 \\
\hline
\end{tabular}

\begin{tabular}{|c|c|c|c|}
\hline \multicolumn{4}{|c|}{ Descriptive Statistics } \\
\hline & Mean & Std. Deviation & $\mathrm{N}$ \\
\hline$y$ & 8450.0000 & 6325.77699 & 12 \\
\hline $\mathrm{x} 1$ & -.5000 & .90453 & 12 \\
\hline$x_{2}$ & -.5000 & .90453 & 12 \\
\hline$x_{3}$ & -.5000 & .90453 & 12 \\
\hline$x 4$ & .5000 & .90453 & 12 \\
\hline$\times 5$ & .5000 & .90453 & 12 \\
\hline$\times 6$ & .5000 & .90453 & 12 \\
\hline
\end{tabular}

FiguRE 2. Final model for Example 3.1

\begin{tabular}{|c|c|c|c|c|c|c|}
\hline \multicolumn{7}{|c|}{ Tests of Normality } \\
\hline & \multicolumn{3}{|c|}{ Kolmogorov-Smirnov ${ }^{\text {a }}$} & \multicolumn{3}{|c|}{ Shapiro-Wilk } \\
\hline & Statistic & df & Sig. & Statistic & df & Sig. \\
\hline Unstandardized Residual & .224 & 12 & .100 & .893 & 12 & .130 \\
\hline
\end{tabular}

Figure 3. Test of normal for Example 3.1

Example 3.2. Let $n=6$ and the poor system of the current housing plans $x_{1}$, the limited availability of the residential lands and their usability $x_{2}$, the lack of the governmental service facilitie $x_{3}$, the rural exodus that has conquered the cities $x_{4}$, the lack of the housing units offered $x_{5}$ and the absence of the supervision over offices and real estate companies $x_{6}$. 
TABLE 3. One replicate for Example 3.2.

\begin{tabular}{|c|c|c|c|c|c|c|c|}
\hline Run & $x_{1}$ & $x_{2}$ & $x_{3}$ & $x_{4}$ & $x_{5}$ & $x_{6}$ & $\mathrm{Y}$ \\
\hline 1 & + & + & - & + & + & + & 1000 \\
2 & - & + & + & + & + & + & 4000 \\
3 & + & - & + & + & + & + & 6800 \\
4 & - & - & - & + & - & + & 4000 \\
5 & - & - & - & + & + & - & 7000 \\
6 & - & - & - & - & + & + & 55000 \\
7 & - & + & - & + & + & + & 2400 \\
8 & - & - & + & + & + & + & 7000 \\
9 & + & - & - & + & + & + & 4855 \\
10 & - & - & - & - & - & + & 2000 \\
11 & - & - & - & + & - & - & 3000 \\
12 & - & - & - & - & + & - & 4000 \\
\hline
\end{tabular}

Now an analysis data in Table 3 (using liner regression) with the software package SPSS. According to the findings of the final model it tends to be seen that the p-value from the Analysis of Variances table (Figure 4) is under 0.05 that revealed there are active variables the poor system of the current housing plans $x_{1}$, the limited availability of the residential lands and their usability $x_{2}$ the rural exodus that has conquered the cities $x_{4}$, and the lack of the housing units offered $x_{5}$ and give an estimated liner model $Y=18075-764.5 x_{1}-2078.25 x_{2}+885.5 x_{4}+151.5 x_{5}+\epsilon$, with $R-s g=94.6 \% \epsilon$ of mean 4296.25 and standard deviation $\sigma=2007.43$. Also from the result, the residual is normal because p-value (0.965) is more than 0.05( See Figure 5). 


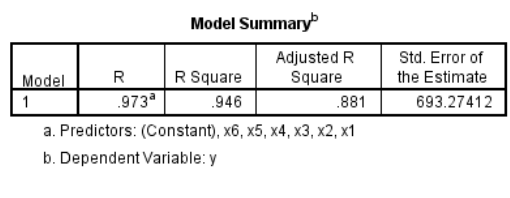

\begin{tabular}{|c|c|c|c|c|c|c|}
\hline \multicolumn{7}{|c|}{ ANOVA $^{a}$} \\
\hline Model & & $\begin{array}{l}\text { Sum of } \\
\text { Squares }\end{array}$ & df & Mean Square & $\mathrm{F}$ & Sig. \\
\hline \multirow[t]{3}{*}{1} & Regression & 41924711.25 & 6 & 6987451.875 & 14.538 & $.005^{\mathrm{b}}$ \\
\hline & Residual & 2403145.000 & 5 & 480629.000 & & \\
\hline & Total & 44327856.25 & 11 & & & \\
\hline
\end{tabular}

a. Dependent Variable: $y$

b. Predictors: (Constant), $\times 6, \times 5, \times 4, \times 3, \times 2, \times 1$

\begin{tabular}{|l|r|r|r|}
\multicolumn{5}{c|}{ Descriptive Statistics } \\
\hline & \multicolumn{1}{|c|}{ Mean } & \multicolumn{1}{|c|}{ Std. Deviation } & \multicolumn{1}{c|}{ N } \\
\hline $\mathrm{y}$ & 4296.2500 & 2007.43745 & 12 \\
$\times 1$ & -.5000 & .90453 & 12 \\
$\times 2$ & -.5000 & .90453 & 12 \\
$\times 2$ & -5000 & .90453 & 12 \\
$\times 34$ & .5000 & .90453 & 12 \\
$\times 5$ & .5000 & .90453 & 12 \\
$\times 6$ & .5000 & .90453 & 12 \\
\hline
\end{tabular}

\begin{tabular}{|c|c|c|c|c|c|c|}
\hline \multicolumn{7}{|c|}{ Coefficients $^{\mathrm{a}}$} \\
\hline & & \multicolumn{2}{|c|}{ Unstandardized Coefficients } & \multirow{2}{*}{$\begin{array}{c}\begin{array}{c}\text { Standardized } \\
\text { Coefficients }\end{array} \\
\text { Beta }\end{array}$} & \multirow[b]{2}{*}{$t$} & \multirow[b]{2}{*}{ Sig. } \\
\hline \multicolumn{2}{|c|}{ Model } & B & Std. Error & & & \\
\hline 1 & (Constant) & 1807.500 & 632.870 & & 2.856 & .036 \\
\hline & $\mathrm{x} 1$ & -764.500 & 290.017 & -344 & -2.636 & .046 \\
\hline & $x_{2}$ & -2078.250 & 290.017 & -.936 & -7.166 & .001 \\
\hline & $\times 3$ & 521.750 & 290.017 & 235 & 1.799 & 132 \\
\hline & $\times 4$ & 885.500 & 290.017 & 399 & 3.053 & .028 \\
\hline & $\times 5$ & 1510.500 & 290.017 & 681 & 5.208 & .003 \\
\hline & $\times 6$ & 260.500 & 290.017 & 117 & .898 & .410 \\
\hline
\end{tabular}

Figure 4. Final model for Example 3.2

\begin{tabular}{|c|c|c|c|c|c|c|}
\hline \multicolumn{1}{|c|}{ Tests of Normality } \\
\cline { 2 - 8 } & \multicolumn{3}{|c|}{ Kolmogorov-Smirnov $^{\mathrm{a}}$} & \multicolumn{3}{c|}{ Shapiro-Wilk } \\
\cline { 2 - 8 } & Statistic & \multicolumn{1}{c|}{ df } & \multicolumn{1}{c|}{ Sig. } & Statistic & \multicolumn{1}{c|}{ df } & Sig. \\
\hline Unstandardized Residual & .110 & 12 & .200 & .976 & 12 & .965 \\
\hline
\end{tabular}

Figure 5. Test of normal for Example 3.2

Example 3.3. Let $n=6$ and the natural factors and climate (earth quick) $x_{1}$, landowners monopolization of the lands and not investing in them $x_{2}$, the poor system of the current housing plans $x_{3}$, the limited availability of the residential lands and their usability $x_{4}$, The lack of the governmental service facilities $x_{5}$ and The rural exodus that has conquered the cities $x_{6}$. 
TABle 4. One replicate for Example 3.3.

\begin{tabular}{|c|c|c|c|c|c|c|c|}
\hline Run & $x_{1}$ & $x_{2}$ & $x_{3}$ & $x_{4}$ & $x_{5}$ & $x_{6}$ & $\mathrm{Y}$ \\
\hline 1 & + & + & - & + & + & + & 3000 \\
2 & - & + & + & + & + & + & 2500 \\
3 & + & - & + & + & + & + & 10000 \\
4 & - & - & - & + & - & + & 5000 \\
5 & - & - & - & + & + & - & 800 \\
6 & - & - & - & - & + & + & 6000 \\
7 & - & + & - & + & + & + & 5000 \\
8 & - & - & + & + & + & + & 14000 \\
9 & + & - & - & + & + & + & 7000 \\
10 & - & - & - & - & - & + & 10000 \\
11 & - & - & - & + & - & - & 5600 \\
12 & - & - & - & - & + & - & 10000 \\
\hline
\end{tabular}

Now an analysis data in Table 4 (using liner regression) with the software package SPSS. According to the findings of the final model it tends to be seen that the p-value from the Analysis of Variances table (Figure 6) is under 0.05 that revealed there is active variable $x_{1}$ the lack of the governmental service facilities and give an estimated liner model $Y=-703.33-4022 x_{1}+\epsilon$, with $R-s g=86.6 \% \epsilon$ of mean 5061.66 and standard deviation $\sigma=4777.55$. Also from the result, the residual is normal because p-value (0.983) is more than 0.05 (See figure 7 ). 


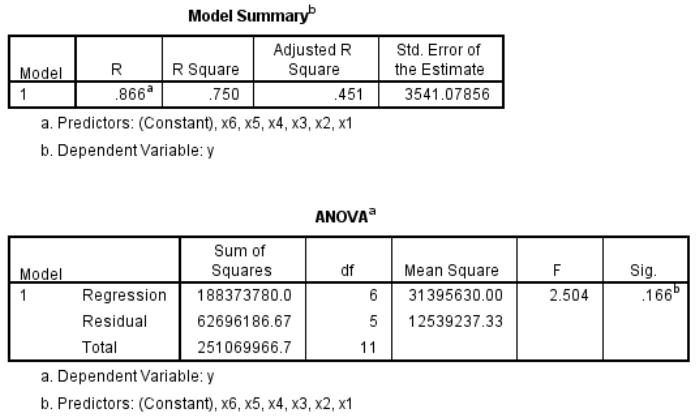

Descriptive Statistics
\begin{tabular}{|l|r|r|r|}
\hline & \multicolumn{1}{|c|}{ Mean } & Std. Deviation & \multicolumn{1}{c|}{ N } \\
\hline $\mathrm{y}$ & 5061.6667 & 4777.50379 & 12 \\
$\mathrm{\times 1}$ & -.5000 & .90453 & 12 \\
$\times 2$ & -.5000 & .90453 & 12 \\
$\times 3$ & -.5000 & .90453 & 12 \\
$\times 4$ & .5000 & .90453 & 12 \\
$\times 5$ & .5000 & .90453 & 12 \\
$\times 6$ & .5000 & .90453 & 12 \\
\hline
\end{tabular}

\begin{tabular}{|c|c|c|c|c|c|c|}
\hline \multicolumn{7}{|c|}{ Coefficients $^{a}$} \\
\hline & & \multicolumn{2}{|c|}{ Unstandardized Coefficients } & \multirow{2}{*}{$\begin{array}{c}\text { Standardized } \\
\text { Coefficients } \\
\text { Beta } \\
\end{array}$} & \multirow[b]{2}{*}{ t } & \multirow[b]{2}{*}{ Sig. } \\
\hline \multicolumn{2}{|c|}{ Model } & B & Std. Error & & & \\
\hline 1 & $\begin{array}{l}\text { (Constant) } \\
\end{array}$ & -703.333 & 3232.548 & & -.218 & .836 \\
\hline & $\mathrm{x} 1$ & -4022.000 & 1481.339 & -.761 & -2.715 & .042 \\
\hline & $\mathrm{x} 2$ & -1022.000 & 1481.339 & -193 & -.690 & .521 \\
\hline & $x 3$ & 768.000 & 1481.339 & 145 & .518 & .626 \\
\hline & $x 4$ & 1243.000 & 1481.339 & 235 & .839 & .440 \\
\hline & $\times 5$ & 3518.000 & 1481.339 & .666 & 2.375 & .064 \\
\hline & $x 6$ & 2493.000 & 1481.339 & .472 & 1.683 & 153 \\
\hline
\end{tabular}

Figure 6. Final model for Example 3.3

\begin{tabular}{|c|c|c|c|c|c|c|}
\hline \multicolumn{7}{|c|}{ Tests of Normality } \\
\hline & Statistic & $\mathrm{df}$ & Sig. & Statistic & df & Sig. \\
\hline Unstandardized Residual & .130 & 12 & $200^{\prime \prime}$ & .980 & 12 & .983 \\
\hline
\end{tabular}

Figure 7. Test of normal for Example 3.3

Moreover, from the model and research, it can be concluded that the examination with the edge plans and regression analysis given results that are associated and just like the investigation that is performed with the whole data. In this manner, the poor system of the current housing plans, the poor system of the current housing plans, the limited availability of the residential lands and their usability, the rural exodus that has conquered the cities, and the lack of the housing units offered and the lack of the governmental service facilities are the factor that driven to the housing crisis in Saudi society. 
3.2. Application of the supersaturated designs in screening experiments. Statistical significance was analyzed using supersaturated designs with the SPSS computer software to determine the actual causes that led to of the housing crisis in Saudi society. [6]who presented a technique for examining SSDs that utilizing another agreements based strategy. Supersaturated plans are partial factorial plans in which the run size (n) is too little to even consider assessing every one of the fundamental impacts. Under the impact sparsity supposition, the utilization of supersaturated plan can give the minimal effort distinguishing proof of the trivial few, potentially ruling components (screening). In order to address these ethical concerns, the following example are taken.

\section{Example 3.4.}

In this example, we assume $n=16$ that shown in Table 5. Examination of these information (Forward

TABLE 5. Supersaturated design(SSD) for Example 3.4.

\begin{tabular}{|c|c|c|c|c|c|c|c|c|c|c|c|c|c|c|c|c|c|}
\hline Run & $x_{1}$ & $x_{2}$ & $x_{3}$ & $x_{4}$ & $x_{5}$ & $x_{6}$ & $x_{7}$ & $x_{8}$ & $x_{9}$ & $x_{10}$ & $x_{11}$ & $x_{12}$ & $x_{13}$ & $x_{14}$ & $x_{15}$ & $x_{16}$ & $\mathrm{Y}$ \\
\hline 1 & - & + & - & - & - & - & + & - & + & - & + & - & + & + & - & + & 0 \\
2 & + & + & - & - & - & + & + & + & + & + & + & + & - & - & + & + & 9400 \\
3 & + & + & - & + & + & + & + & + & + & + & + & - & + & - & - & + & 7000 \\
4 & + & + & - & + & + & + & + & - & + & - & - & + & + & + & + & + & 1500 \\
5 & + & - & - & - & + & + & - & - & + & + & + & + & + & - & + & + & 0 \\
6 & - & + & - & + & - & + & - & + & + & + & - & - & - & - & - & + & 0 \\
7 & + & - & - & + & - & + & - & - & - & - & - & - & + & - & + & - & 12000 \\
8 & + & - & - & + & - & + & - & - & - & - & - & - & + & - & + & - & 12000 \\
9 & - & - & - & + & + & + & - & - & + & - & - & - & - & - & - & - & 8700 \\
10 & - & - & - & - & + & - & - & - & - & + & - & + & + & + & - & - & 0 \\
11 & + & + & + & + & + & + & - & - & - & - & - & - & - & - & - & + & 9000 \\
12 & - & - & - & - & + & + & + & + & - & - & - & - & - & - & - & + & 6000 \\
13 & + & - & - & + & + & + & - & + & + & + & - & - & + & + & + & + & 0 \\
14 & - & - & + & - & - & - & + & - & - & - & - & + & - & - & - & - & 34000 \\
\hline
\end{tabular}

determination) with program bundle SPSS. According to the findings of the final model it tends to be seen that the p-value from the Analysis of Variances table (Figure 8) is under 0.05 that uncovers as dynamic factors $x_{3}, x_{16}, x_{7}, x_{14}, x_{15}$ and $x_{8}$, an assessed direct demonstrate is:

$$
y=15113.78+8046.65 x_{3}-6461.90 x_{16}+4094.22 x_{7}-2459.401 x_{14}+2116.295 x_{15}+2003.552 x_{8}+\varepsilon
$$

with $\epsilon$ of mean 7114.28 and standard deviation $\sigma=9062.67$. Also from the result, the residual is normal because p-value (0.384) is more than 0.05 (See figure 9 ). 


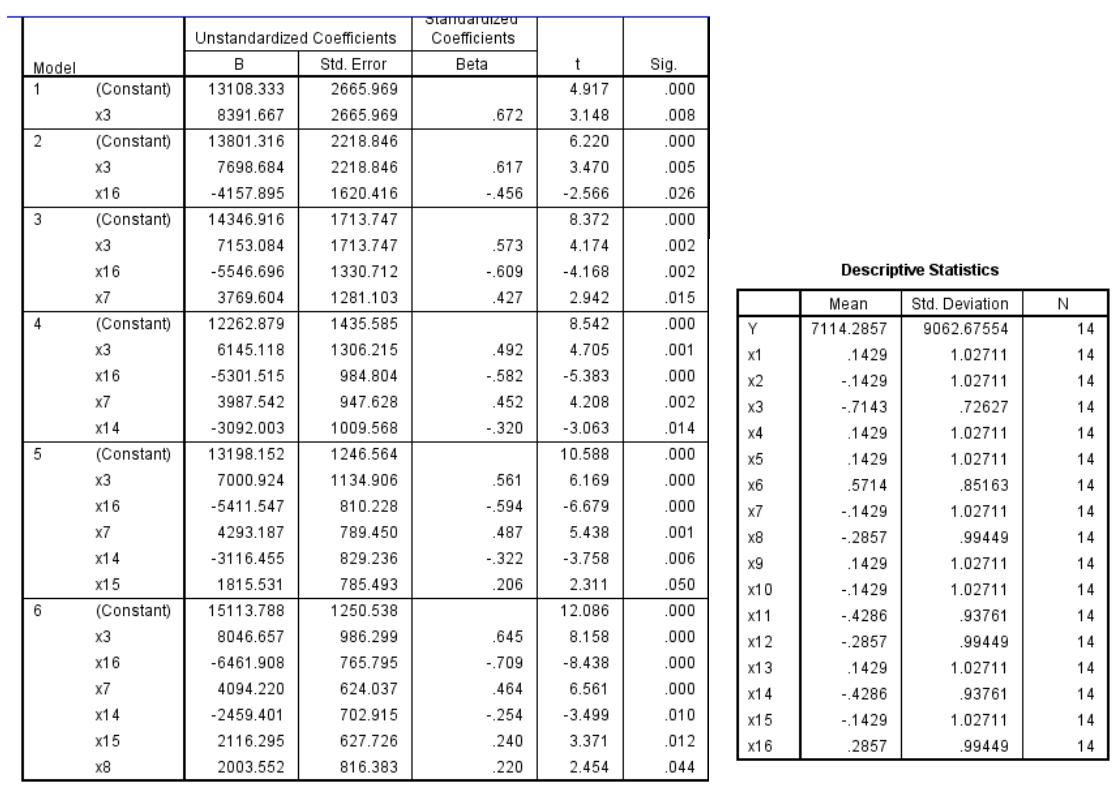

Figure 8. Final model for Example 3.4

\begin{tabular}{|c|c|c|c|c|c|c|}
\hline \multicolumn{7}{|c|}{ Tests of Normality } \\
\hline & \multicolumn{3}{|c|}{ Kolmogorov-Smirnov } & \multicolumn{3}{|c|}{ Shapiro-Wilk } \\
\hline & Statistic & $d f$ & Sig. & Statistic & $d f$ & Sig. \\
\hline Unstandardized Residual & .152 & 14 & $.200^{\circ}$ & .937 & 14 & .384 \\
\hline
\end{tabular}

Figure 9. Test of normal for Example 3.4 


\section{Example 3.5.}

TABLE 6. Supersaturated design(SSD) for Example 3.5.

\begin{tabular}{|c|c|c|c|c|c|c|c|c|c|c|c|c|c|c|c|c|c|}
\hline Run & $x_{1}$ & $x_{2}$ & $x_{3}$ & $x_{4}$ & $x_{5}$ & $x_{6}$ & $x_{7}$ & $x_{8}$ & $x_{9}$ & $x_{10}$ & $x_{11}$ & $x_{12}$ & $x_{13}$ & $x_{14}$ & $x_{15}$ & $x_{16}$ & $\mathrm{Y}$ \\
\hline 1 & - & + & + & + & + & - & - & - & - & - & - & - & - & + & - & - & 22000 \\
2 & + & + & - & - & - & - & - & - & - & - & - & + & - & - & - & - & 15000 \\
3 & - & - & - & - & + & - & - & - & - & - & - & - & - & - & - & - & 9000 \\
4 & + & - & + & - & - & - & - & + & + & - & - & - & + & + & - & - & 3000 \\
5 & + & + & - & + & + & + & - & + & + & + & + & + & + & - & + & + & 3200 \\
6 & + & - & - & - & + & + & - & + & - & - & - & - & - & - & + & - & 1000 \\
7 & - & + & - & - & + & + & + & + & + & - & - & + & + & + & + & + & 1000 \\
8 & - & - & - & - & + & + & + & + & - & - & - & - & - & - & - & + & 6000 \\
9 & + & - & - & + & + & + & - & + & + & + & - & - & - & + & + & + & 990 \\
10 & + & + & + & - & + & - & - & - & - & + & - & - & + & - & + & + & 5600 \\
11 & + & + & + & + & + & + & + & + & + & + & + & + & + & + & - & + & 12344 \\
12 & + & + & + & + & + & + & + & + & + & + & + & + & + & + & + & + & 2000 \\
13 & + & + & + & + & + & - & + & + & + & + & + & + & + & - & + & + & 8700 \\
14 & + & + & - & + & + & + & + & + & - & + & + & + & - & + & + & + & 2600 \\
\hline
\end{tabular}

Analysis of these data based on forward selection on Table 6, according to the findings of the final model it tends to be seen that the p-value from the Analysis of Variances table (Figure 10) is under 0.05 that there are two active variables $x_{2} a n d x_{15}$. The estimated linear model:

$$
y=8348.688-4875.313 x_{15}+3325.75 x_{2}+\varepsilon .
$$

with $\epsilon$ of mean 6602.42 and standard deviation $\sigma=6251.82$. Also from the result, the residual is normal because p-value (0.590) is more than 0.05 (See figure 11). 


\begin{tabular}{|c|c|c|c|}
\hline \multicolumn{4}{|c|}{ Descriptive Statistics } \\
\hline & Mean & Std. Deviation & $\mathrm{N}$ \\
\hline$\overline{\mathrm{Y}}$ & 6602.4286 & 6251.86467 & 14 \\
\hline $\mathrm{x} 1$ & 4286 & .93761 & 14 \\
\hline x2 & 2857 & 99449 & 14 \\
\hline$x 3$ & -.1429 & 1.02711 & 14 \\
\hline $\mathrm{x} 4$ & .0000 & 1.03775 & 14 \\
\hline x5 & .7143 & .72627 & 14 \\
\hline$x_{6}$ & 1429 & 1.02711 & 14 \\
\hline $\mathrm{x} 7$ & -.1429 & 1.02711 & 14 \\
\hline$x 8$ & 4286 & .93761 & 14 \\
\hline x9 & .0000 & 1.03775 & 14 \\
\hline$x 10$ & .0000 & 1.03775 & 14 \\
\hline $\mathrm{x} 11$ & -.2857 & 99449 & 14 \\
\hline $\mathrm{x} 12$ & .0000 & 1.03775 & 14 \\
\hline$x 13$ & .0000 & 1.03775 & 14 \\
\hline $\mathrm{x} 14$ & .0000 & 1.03775 & 14 \\
\hline $\mathrm{x} 15$ & .1429 & 1.02711 & 14 \\
\hline $\mathrm{x} 16$ & 2857 & .99449 & 14 \\
\hline
\end{tabular}

\begin{tabular}{|c|c|c|c|c|c|c|}
\hline \multicolumn{7}{|c|}{ Coefficients $^{a}$} \\
\hline & & \multicolumn{2}{|c|}{ Unstandardized Coefficients } & $\begin{array}{c}\text { Standardized } \\
\text { Coefficients }\end{array}$ & \multirow[b]{2}{*}{$t$} & \multirow[b]{2}{*}{ Sig. } \\
\hline \multicolumn{2}{|c|}{ Model } & $B$ & Std. Error & Beta & & \\
\hline \multirow[t]{2}{*}{1} & $\begin{array}{l}\text { (Constant) } \\
\end{array}$ & 7180.125 & 1313.303 & & 5.467 & .000 \\
\hline & $\times 15$ & -4043.875 & 1313.303 & -.664 & -3.079 & .010 \\
\hline \multirow[t]{3}{*}{2} & (Constant) & 6348.688 & 1035.998 & & 6.128 & .000 \\
\hline & x15 & -4875.313 & 1035.998 & -.801 & -4.706 & .001 \\
\hline & $x_{2}$ & 3325.750 & 1069.974 & .529 & 3.108 & .010 \\
\hline
\end{tabular}

FIgURE 10. Final model for Example 3.5

\begin{tabular}{|c|c|c|c|c|c|c|}
\hline \multicolumn{3}{|c|}{ Tests of Normality } \\
\cline { 2 - 8 } & \multicolumn{3}{|c|}{ Kolmogorov-Smirnov $^{\mathrm{a}}$} & \multicolumn{3}{c|}{ Shapiro-Wilk } \\
\cline { 2 - 7 } & Statistic & \multicolumn{1}{c|}{ df } & \multicolumn{1}{c|}{ Sig. } & Statistic & \multicolumn{1}{c|}{ df } & Sig. \\
\hline Unstandardized Residual & .180 & 14 & .200 & .952 & 14 & .590 \\
\hline
\end{tabular}

Figure 11. Test of normal for Example 3.5

Example 3.6.

TABle 7. Supersaturated design(SSD) for Example 3.6.

\begin{tabular}{|c|c|c|c|c|c|c|c|c|c|c|c|c|c|c|c|c|c|}
\hline Run & $x_{1}$ & $x_{2}$ & $x_{3}$ & $x_{4}$ & $x_{5}$ & $x_{6}$ & $x_{7}$ & $x_{8}$ & $x_{9}$ & $x_{10}$ & $x_{11}$ & $x_{12}$ & $x_{13}$ & $x_{14}$ & $x_{15}$ & $x_{16}$ & $\mathrm{Y}$ \\
\hline 1 & - & - & - & + & - & - & + & - & - & - & - & - & - & - & - & - & 1000 \\
2 & - & - & - & - & - & - & + & - & - & - & - & + & - & - & - & - & 3000 \\
3 & - & - & + & - & - & - & + & - & - & - & - & - & + & - & - & - & 0 \\
4 & - & - & - & - & - & - & - & - & - & + & - & + & - & - & + & + & 0 \\
5 & - & - & + & - & - & - & + & - & - & - & - & - & + & - & - & - & 0 \\
6 & + & + & - & - & + & + & - & + & + & + & - & + & + & - & + & + & 0 \\
7 & - & + & - & - & + & + & + & + & + & + & + & - & - & + & + & + & 12670 \\
8 & - & + & - & - & + & + & - & + & + & + & + & - & + & + & + & + & 0 \\
9 & - & + & - & + & + & + & - & + & - & + & + & - & + & + & + & + & 10000 \\
10 & - & + & - & - & + & + & - & + & + & + & - & + & - & + & + & + & 0 \\
11 & + & - & - & - & + & - & - & - & - & - & - & - & + & + & + & + & 5500 \\
12 & + & - & + & + & + & + & - & - & - & - & - & - & - & + & + & + & 0 \\
13 & + & - & - & - & + & + & - & + & + & + & + & + & + & + & + & + & 10000 \\
14 & - & + & - & + & + & + & - & + & + & + & - & + & + & + & + & + & 10000 \\
\hline
\end{tabular}


Analysis of these data based on forward selection on Table 7, according to the findings of the final model it tends to be seen that the p-value from the Analysis of Variances table (Figure 12) is under 0.05 that there is active variable $x_{11}$. The estimated linear model: with $\epsilon$ of mean 3762.42 and standard deviation $\sigma=4854.58$. Also from the result, the residual is normal because p-value (0.197) is more than 0.05(See figure 13).

\begin{tabular}{|c|c|c|c|}
\hline \multicolumn{4}{|c|}{ Descriptive } \\
\hline & Mean & Std. Deviation & $\mathrm{N}$ \\
\hline $\bar{Y}$ & 3726.4286 & 4854.58642 & 14 \\
\hline $\mathrm{x} 1$ & -.4286 & .93761 & 14 \\
\hline $\mathrm{x} 2$ & -.1429 & 1.02711 & 14 \\
\hline$x 3$ & -.5714 & .85163 & 14 \\
\hline$x 4$ & -.4286 & .93761 & 14 \\
\hline x5 & .2857 & .99449 & 14 \\
\hline$x 6$ & .1429 & 1.02711 & 14 \\
\hline$x 7$ & -.2857 & .99449 & 14 \\
\hline x8 & .0000 & 1.03775 & 14 \\
\hline x9 & -.1429 & 1.02711 & 14 \\
\hline$x 10$ & .1429 & 1.02711 & 14 \\
\hline$x 11$ & -.4286 & 93761 & 14 \\
\hline$x 12$ & -.1429 & 1.02711 & 14 \\
\hline$x 13$ & .1429 & 1.02711 & 14 \\
\hline$x 14$ & .1429 & 1.02711 & 14 \\
\hline x15 & .4286 & .93761 & 14 \\
\hline $\mathrm{x} 16$ & .4286 & .93761 & 14 \\
\hline
\end{tabular}

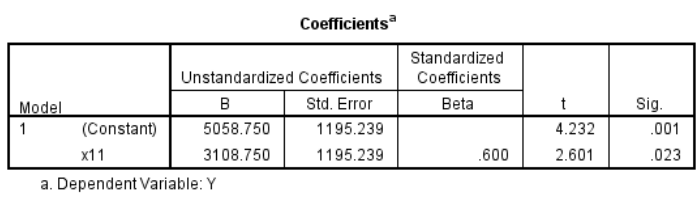

FIgURE 12. Final model for Example 3.6

\begin{tabular}{|c|c|c|c|c|c|c|}
\hline \multicolumn{3}{|c|}{ Tests of Normality } \\
\cline { 2 - 8 } & \multicolumn{3}{|c|}{ Kolmogorov-Smirnov ${ }^{\mathrm{a}}$} & \multicolumn{3}{|c|}{ Shapiro-Wilk } \\
\cline { 2 - 8 } & Statistic & \multicolumn{1}{c|}{$\mathrm{df}$} & \multicolumn{1}{c|}{ Sig. } & Statistic & \multicolumn{1}{c|}{ df } & Sig. \\
\hline Unstandardized Residual & .236 & 14 & .033 & .917 & 14 & .197 \\
\hline
\end{tabular}

Figure 13. Test of normal for Example 3.6

Moreover, from the model and research, it can be concluded that the examination with the Supersaturated design and regression analysis given results that are associated and just like the investigation that is performed with the whole data. In this manner the lack of the citizen's culture of the importance of house owning, the religion contributed in the housing crisis by prohibiting the works of the banks, the natural factors and climate (earth quick), landowners monopolization of the lands and not investing in them, The absence of the supervision over offices and real estate companies, the increasing of building materials and manpower prices and real estate developer's' exploitation of residential lands and the lack of the governmental service facilities are the factor that driven to the housing crisis in Saudi society. 


\section{Discussion}

During this examination, it was noticed that there has been a lessening in the course of the most recent couple of years in the quantity of scholarly investigations being embraced that emphasis on the examination of this issue according to the perspective of the inhabitants and their cravings. One of the points of this consider was to consider the genuine causes that driven to the spread of the actual causes of the housing crisis .Statistical signi

cance was dissected utilizing edge design, Supersaturated design with the regression examination utilizing the SPSS computer computer program to decide the actual causes that driven to the actual causes of the housing crisis in Saudi society. I can say that the examination with the edge plans and Supersaturated design given results that are associated and just like the investigation that is performed with the whole data. In this manner, tthe lack of the governmental service facilities is the factor that driven to the housing crisis in Saudi society. On this premise, it is suggested that Saudi wellbeing experts create an operational arrange to consider the maladies and crises that the housing crisis. On this basis, it is recommended that Saudi goverment develop an operational plan to study these causes. In future investigations, it might be possible for data to use supersaturated designs, where many factors are investigated using only a few experimental runs. Furthermore, there is a requirement for more research thinks about that address different parts of diabetes in the Saudi setting, for example, the extent of this phenomenon with three levels $(+, 0,-)$.

Acknowledgment. I might want to thank the University of Ha'il in Saudi Arabia for monetarily supporting my exploration project.

Ethics endorsement and agree to participate. Not relevant

Availability of information and material. The information upholds the finding of this investigation are accessible inside the article and its advantageous material.

Funding. Not relevant

Conflicts of Interest: The author(s) declare that there are no conflicts of interest regarding the publication of this paper.

\section{REFERENCES}

[1] C. Susilawati, M. Al Surf, Challenges facing sustainable housing in saudi arabia: a current study showing the level of public awareness, in: Proceedings of the 17th Annual Pacific Rim Real Estate Society Conference, Pacific Rim Real Estate Society, 2011, pp. 1-12.

[2] Ministry of Municipal \& Rural Affairs, Saudi cities report 2019, https://unhabitat.org/saudi-cities-report-2019, (2019).

[3] M.H. Aldebasi, N.A. Alsobaie, A.Y. Aldayel, K.M. Alwusaidi, T. Alasbali, Public Awareness regarding the Differences between Ophthalmologists and Optometrists among Saudi Adults Living in Riyadh: A Quantitative Study, J. Ophthalmol. 2018 (2018), 7418269. 
[4] C. Elster, A. Neumaier, Screening by conference designs, Biometrika, 82(3) (1995), 589-602.

[5] T. Alanazi, S. Georgiou, S. Stylianou, Construction and analysis of edge designs from skew-symmetric supplementary difference sets, Commun. Stat.-Theory Meth. 47(20) (2018), 5064-5076.

[6] C. Koukouvinos, S. Stylianou, A Method for Analyzing Supersaturated Designs, Commun. Stat.-Simul. Comput. 34 (2005), 929-937. 